University of Nebraska - Lincoln

DigitalCommons@University of Nebraska - Lincoln

USDA National Wildlife Research Center - Staff Publications
U.S. Department of Agriculture: Animal and Plant Health Inspection Service

2011

\title{
Hair of the Dog: Obtaining Samples From Coyotes and Wolves Noninvasively
}

\author{
David E. Ausband \\ Montana Cooperative Wildlife Research Unit, University of Montana, Missoula, MT \\ Julie K. Young \\ Wildland Resources Department, Utah State University, Logan, julie.k.young@aphis.usda.gov \\ Barbara Fannin \\ Montana Cooperative Wildlife Research Unit, University of Montana, Missoula, MT \\ Michael S. Mitchell \\ USGS Montana Cooperative Wildlife Research Unit, University of Montana, Missoula, MT \\ Jennifer L. Stenglen \\ Department of Fish \& Wildlife Resources, University of Idaho, Moscow, ID \\ See next page for additional authors
}

Follow this and additional works at: https://digitalcommons.unl.edu/icwdm_usdanwrc

Part of the Environmental Sciences Commons, and the Life Sciences Commons

Ausband, David E.; Young, Julie K.; Fannin, Barbara; Mitchell, Michael S.; Stenglen, Jennifer L.; Waits, Lizette P.; and Shivik, John A., "Hair of the Dog: Obtaining Samples From Coyotes and Wolves Noninvasively" (2011). USDA National Wildlife Research Center - Staff Publications. 1012. https://digitalcommons.unl.edu/icwdm_usdanwrc/1012

This Article is brought to you for free and open access by the U.S. Department of Agriculture: Animal and Plant Health Inspection Service at DigitalCommons@University of Nebraska - Lincoln. It has been accepted for inclusion in USDA National Wildlife Research Center - Staff Publications by an authorized administrator of DigitalCommons@University of Nebraska - Lincoln. 


\section{Authors}

David E. Ausband, Julie K. Young, Barbara Fannin, Michael S. Mitchell, Jennifer L. Stenglen, Lizette P. Waits, and John A. Shivik 


\title{
Hair of the Dog: Obtaining Samples From Coyotes and Wolves Noninvasively
}

\author{
DAVID E. AUSBAND, ${ }^{\mathbf{1}}$ Montana Cooperative Wildife Research Unit, 205 Natural Sciences Building, University of Montana, Missoula, \\ MT 59812, USA \\ JULIE YOUNG, Wildland Resources Department, Utah State University, Logan, UT 84322-5230, USA \\ BARBARA FANNIN, Montana Cooperative Wildife Research Unit, 205 Natural Sciences Building, University of Montana, Missoula, \\ MT 59812, USA \\ MICHAEL S. MITCHELL, United States Geological Survey, Montana Cooperative Wildlife Research Unit, 205 Natural Sciences Building, \\ University of Montana, Missoula, MT 59812, USA \\ JENNIFER L. STENGLEIN, Department of Fish \& Wildlife Resources, University of Idaho, Moscow, ID 83844, USA \\ LISETTE P. WAITS, Department of Fish E Wildlife Resources, University of Idaho, Moscow, ID 83844, USA \\ JOHN A. SHIVIK, Wildland Resources Department, Utah State University, Logan, UT 84322-5230, USA
}

\begin{abstract}
Canids can be difficult to detect and their populations difficult to monitor. We tested whether hair samples could be collected from coyotes (Canis latrans) in Texas, USA and gray wolves (C. lupus) in Montana, USA using lure to elicit rubbing behavior at both man-made and natural collection devices. We used mitochondrial and nuclear DNA to determine whether collected hair samples were from coyote, wolf, or nontarget species. Both coyotes and wolves rubbed on man-made barbed surfaces but coyotes in Texas seldom rubbed on hanging barbed surfaces. Wolves in Montana showed a tendency to rub at stations where naturalmaterial collection devices (sticks and debris) were present. Time to detection was relatively short (5 nights and 4 nights for coyotes and wolves, respectively) with nontarget and unknown species comprising approximately $26 \%$ of the detections in both locations. Eliciting rubbing behavior from coyotes and wolves using lures has advantages over opportunistic genetic sampling methods (e.g., scat transects) because it elicits a behavior that deposits a hair sample at a fixed sampling location, thereby increasing the efficiency of sampling for these canids. Hair samples from rub stations could be used to provide estimates of abundance, measures of genetic diversity and health, and detection-nondetection data useful for cost-effective population monitoring. (c) 2011 The Wildlife Society.
\end{abstract}

KEY WORDS Canis latrans, Canis lupus, coyote, DNA, gray wolf, monitoring, noninvasive sampling.

Carnivores can be difficult to detect and, thus, monitor (MacKay et al. 2008). Many studies have attempted to develop or evaluate methods for monitoring carnivore populations (Sargeant et al. 2003, Smith et al. 2007, Long and Zielinski 2008, Balme et al. 2009). Canid populations in particular have been surveyed using a wide array of techniques including trapping, scent-stations, cameras, scat surveys, and noninvasive genetic sampling (Andelt and Andelt 1984, Schauster et al. 2002, Gompper et al. 2006, Kelly and Holub 2008, Ausband et al. 2010, Stenglein et al. 2010). While some of these survey methods are useful for estimating abundance, noninvasive genetic sampling is quite powerful because, in addition to providing estimates of abundance with precision (Kendall et al. 2009, Stenglein et al. 2010), it can provide a wide array of information ranging from diet to measures of relatedness, hybridization, and spatial organization (Schwartz and Monfort 2008, McCall 2009).

Received: 31 January 2011; Accepted: 13 April 2011;

Published: 19 May 2011

${ }^{1}$ E-mail: david.ausband@mso.umt.edu
Genetic sampling for canids has largely been limited to opportunistic scat-survey techniques (Kohn et al. 1999, Prugh et al. 2005, Marucco et al. 2009) where detection at a sampled location is dependent on 3 events, each with relatively low probabilities of happening simultaneously at any one location: 1) the animal being present, 2) the animal depositing a scat, and 3) an observer detecting the scat. Because canids occupy large home ranges and occur at low densities, opportunistic sampling has a high probability of failing to detect canids when they are present.

New approaches have been developed recently to obtain hair samples noninvasively from carnivores, where lure is used to attract the animal to a sampling point and a collection device (e.g., barbs on a wire) facilitates the deposit of a sample (Kendall and McKelvey 2008). DNA obtained from hair collected noninvasively has been used to generate estimates of abundance for wide-ranging low-density carnivores such as grizzly bear (Ursus arctos), black bear (U. americanus), and American marten (Martes americana; Foran et al. 1997, Woods et al. 1999, Mowat and Strobeck 2000). Conversely, no evaluation of methods for collecting hairs noninvasively from coyotes (Canis latrans) or wolves (C. lupus) has been published (Kendall and McKelvey 2008). Some studies have 
detected coyotes and wolves inadvertently when surveying for other species, with hair corrals and barbed posts being the most common techniques used (Ruell and Crooks 2007, Kendall and McKelvey 2008). Pilot testing of such methods in Montana, USA indicated coyotes and wolves were reluctant to enter hair corrals or use barbed posts; in most cases snow-track evidence indicated the animal had approached the corral or post to investigate but would not otherwise interact with the devices (D. E. Ausband, Montana Cooperative Wildlife Research Unit, unpublished data).

Coyotes have been shown to rub in lures containing chemicals that mimic degradation and fermentation of tissues, and rub behavior has been elicited from wolves using novel and malodorous substances (Ryon et al. 1986, Asa and Mech 1995, Kimball et al. 2000). In addition, biologists in the northern Rockies of the United States have observed wolves rubbing in a variety of commercial lures commonly used for trapping (L. Bradley, Montana Fish, Wildlife and Parks, personal communication; M. Jimenez, United States Fish and Wildlife Service, personal communication). Exploiting behavior that encourages the deposition of a sample at a fixed location could improve the efficiency of hair collection over opportunistic sampling. Our goal was to evaluate whether lures and both man-made and natural-material collection devices could be used to noninvasively sample for canids.

\section{STUDY AREA}

We tested man-made rub-station devices on coyotes at the 3,157-ha Rob and Bessie Welder Wildlife Refuge (WWR), north of Sinton, Texas, USA. The WWR was located in a transition zone between the gulf prairies and marshes and South Texas plains (Gould 1975). Annual precipitation averaged $77 \mathrm{~cm}$, and average temperature ranged from $16{ }^{\circ} \mathrm{C}$ in winter to $28{ }^{\circ} \mathrm{C}$ in summer. Resident coyotes were found in up to 9 packs, consisting of 2-3 adults each, and additional transient coyotes occupied WWR (Young 2006).

Our study area in Montana was mountainous and dominated by a mix of ponderosa pine (Pinus ponderosa), lodgepole pine (P. contorta), and spruce (Picea englemannii) forests. Annual precipitation ranged from $89 \mathrm{~cm}$ to $178 \mathrm{~cm}$ and temperatures ranged from $-34{ }^{\circ} \mathrm{C}$ in winter to $38{ }^{\circ} \mathrm{C}$ in summer (Western Regional Climate Center 2009).

\section{METHODS}

\section{Texas: Coyotes}

To make rub-station devices for field-testing at WWR, we placed carpet-tack strips on, or drove screws through, plywood board $(30.5 \mathrm{~cm} \times 15.2 \mathrm{~cm}, \quad 1.3 \mathrm{~cm}$ thick; Fig. 1a,b). Because we were unsure whether coyotes would rub against objects or drop directly to the ground to rub, we hung devices from fence lines and posts or secured them into the ground with 4-penny nails and baited them with a mixture (approx. $5 \mathrm{~mL}$ ) of Government Call and Canine Call (O'Gorman's, Broadus, MT) on or under each device. We minimized effects of human scent by constructing rubstation devices $>2$ months before use in the field. We wore gloves when deploying devices and stored the devices away from human activity between field uses. We checked and reapplied lure (approx. $5 \mathrm{~mL}$ ) at least every 4 nights.

During field-testing, we placed 90 rub-station devices throughout the WWR along fence lines, roads, and game trails during January and July of 2003 and 2004. In 2003 we spaced rub-station devices an average of $320 \mathrm{~m}$ apart, and in 2004 we spaced devices an average of $415 \mathrm{~m}$ apart. We bundled all hairs found at each rub-station device, irrespective of hair type (underfur vs. guard hair), placed them in paper envelopes, and sterilized screws or nails with a lighter. Samples were frozen until subsequent DNA extraction.

\section{Montana: Wolves and Coyotes}

We used lure at man-made rub stations with barbed devices and at natural-material rub stations where no device was present, on both coyotes and gray wolves in northwestern Montana. Coyotes were detected as bycatch when sampling for wolves and we evaluated the efficacy of rub stations to detect coyotes. We designed 3 rub-station devices: 1) $10.2-\mathrm{cm} \times 15.2-\mathrm{cm}$ pieces of plywood with 2-pronged barbed-wire stapled in a loop approximately $1.3 \mathrm{~cm}$ distant from the edge (Fig. 1c), 2) this same design with the addition of 3 0.64-cm-diameter metal-bristled brushes (12-gauge shotgun bore-cleaning brushes) stapled to the center (Fig. 1c), and 3) a 5.1-cm $\times 10.2-\mathrm{cm}$ block of wood with a $2.5-\mathrm{cm}$-diameter metal-bristled brush stapled to the top edge (barbeque-grill-cleaning brushes; Fig. 1c). We tested additional stations with natural-material collection devices where lure was deposited directly on a substrate of sticks (5-6 2.5-cm-diam twigs) and rocks and no man-made collection device (i.e., barb or bristle) was present (Fig. 1d). Based on findings by Kimball et al. (2000) and anecdotal observation during live-trapping, we used 5 different lures in alternating fashion: Mega Musk (Russ Carmen, New Milford, PA), Long Line Canine Call (OLLCC; O'Gorman's), fresh-pressed salmon oil, Montana Special (currently only available for trapping purposes as per the distributor; now using Powder River from same supplier; O'Gorman's) and a homemade mixture of rotten fish. We buried devices under a thin layer (approx. $1.25 \mathrm{~cm}$ ) of dirt and deposited lure $(1.25 \mathrm{~mL})$ on the ground along each device edge for a total of $5 \mathrm{~mL}$ lure at each station. For natural-material collection devices, we deposited $5 \mathrm{~mL}$ lure along the edges $(\mathrm{N}, \mathrm{S}, \mathrm{E}, \mathrm{W})$ of naturally occurring or constructed piles of sticks, branches, logs, or rocks. We boiled tools to eliminate human scent and wore boiled cotton gloves whenever handling devices or materials. After removing all hairs, we sterilized barbs with a lighter, recovered devices with dirt, and rebaited the stations with lure. We checked rub stations every 2 nights for 1 week.

During September-November 2008, we placed rub stations approximately $0.8 \mathrm{~km}$ apart along U.S. Forest Service roads and trails at intersections, curves, and other probable canid travel routes (Vila et al. 1994, Barja et al. 2004) within the territories of 3 wolf packs in northwestern Montana: Big Hole, Trapper Peak, and Ninemile. The Big Hole wolf pack was sampled for 3 periods (7 nights each) using 6 rub stations with man-made devices and 1 period using 

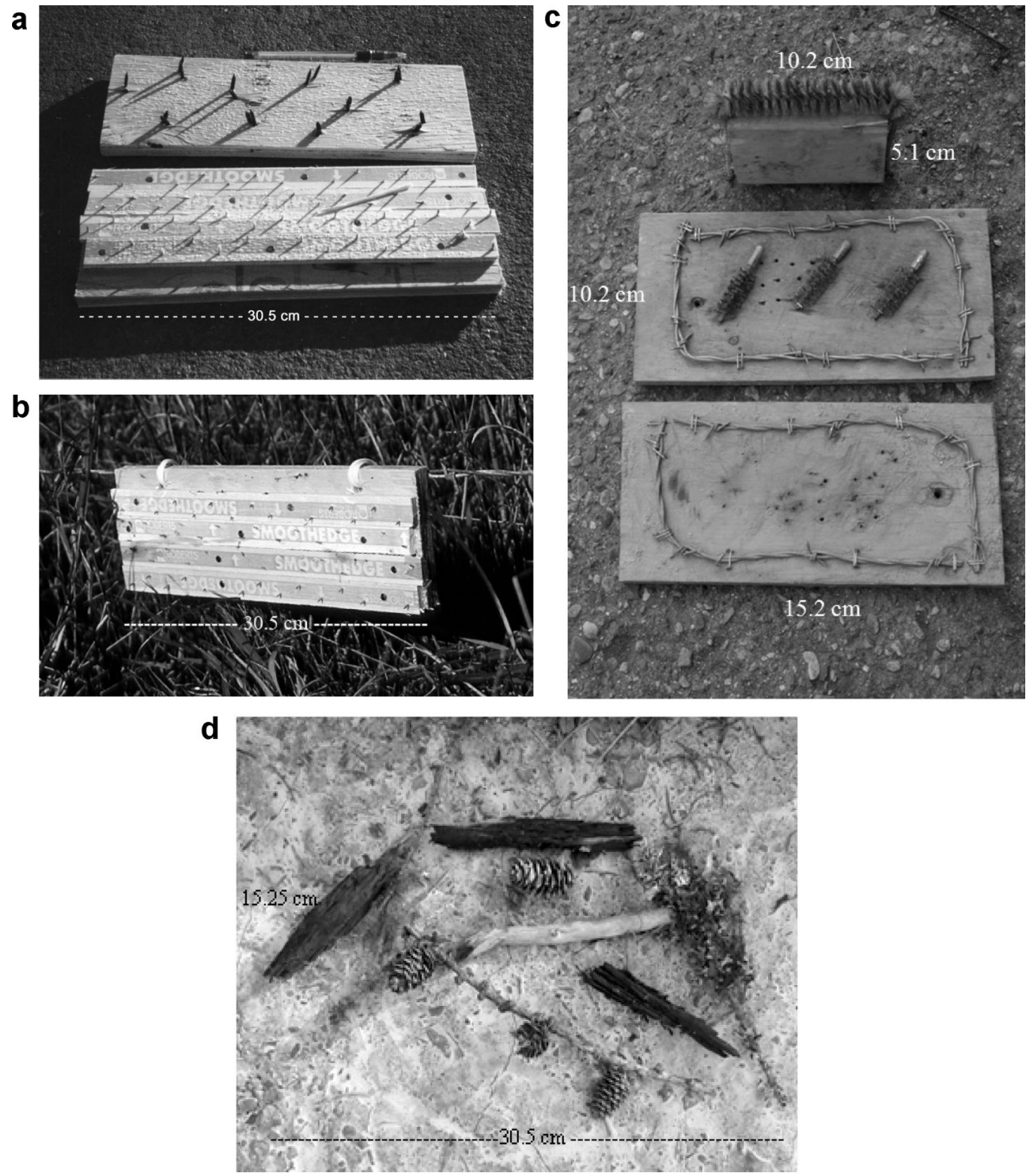

Figure 1. (a-d) Photographs of 5 different man-made rub-station devices and 1 natural-material rub station used to capture hairs from coyotes and wolves in Texas, USA, 2003-2004, and Montana, USA, 2008.

7 natural-material rub stations. The Ninemile wolf pack was sampled once using 6 rub stations with man-made devices and once using 5 natural-material rub stations. The Trapper Peak wolf pack was sampled for 2 periods using 6 rub stations with man-made devices. Each wolf pack had $\geq 1$ radiocollared member and had been monitored closely for a relatively long period of time (U.S. Fish and Wildlife Service, Nez Perce Tribe, National Park Service, and U.S. Department of Agriculture Wildlife Services 2000-2008); therefore, their movement habits and travel routes were well-known and we were reasonably assured wolves would travel near the rub stations while they were deployed. We collected hairs in bundles of 10, irrespective of hair type (underfur vs. guard hair), and placed the samples in paper coin envelopes (Stenglein et al. 2010). Sample envelopes were then stored in a bag with silica desiccant beads prior to DNA extraction.

\section{Analyses}

We performed DNA analysis of hair samples at the University of Idaho Laboratory for Conservation and Ecological Genetics (Moscow, ID). All hairs from each rub event at WWR and 10 hairs (Goossens et al. 1998) from each Big Hole and Ninemile wolf-pack rub events were extracted together using the Qiagen DNeasy tissue kit (Qiagen, Inc., Valencia, CA). Early DNA results from the Big Hole and Ninemile extractions indicated lower than expected success rates; thereafter, we pooled and extracted 20 of the hairs most likely to yield DNA (i.e., guard hairs with visible follicles; Stenglein et al. 2010) that were collected on the same day from each device in Trapper Peak.

We then conducted a mitochondrial DNA (mtDNA) control-region fragment analysis species-identification test to confirm either coyote or wolf origin using the PCR 
(polymerase chain reaction) conditions and methods described in Onorato et al. (2006). Coyote samples produce a 115-120 base pair (bp) PCR product and wolves and dogs produce a 123-128-bp PCR product. Because domestic dog (C. l. familiaris) and wolf produce mtDNA PCR products of the same size, it was necessary to identify potential wolf samples to individuals from 9 microsatellite loci with the primers and protocol outlined in Stenglein et al. (2010). We confirmed identification of an individual after obtaining a consensus genotype of $\geq 7$ loci after 2-5 PCR amplifications. We categorized samples with viable DNA in the species identification test but not belonging to wolves or coyotes as nontarget species (e.g., domestic dog, black bear).

We arcsine-transformed the proportion of positive detections to ensure normally distributed observations (Ramsey and Schafer 2002). We used a Z-test (De Veaux et al. 2004) to examine 1) differences between ground-based and hanging devices, 2) differences between devices constructed of carpet strips or screws, and 3) the efficacy of rub stations with and without devices for detecting wolves.

\section{RESULTS}

\section{Texas: Coyotes}

No coyotes visited rub-station devices in July of either year at WWR, so results refer only to January 2003 and 2004. We observed 95 visits across 179 rub-station deployments, and from those 95 visits, we obtained 73 hair samples from 72 separate rub events. Two hair samples were collected from the same device that appeared, based on tufts of hairs on opposite ends of the device and multiple tracks nearby, to have been left by 2 coyotes or 1 coyote over 2 rub events, and we treated them as separate hair samples (Table 1). Two samples could not be analyzed to species identification because the extracted DNA had desiccated while in storage. Of the remaining 71 samples, coyotes comprised a minimum of $87.3 \%(n=62)$ while $12.7 \%(n=9)$ had insufficient DNA for analysis (Table 1). We checked rub stations every 4 nights, making time to detection measures limited; however, most $(62.9 \%)$ coyote detections occurred within the first 2 sampling periods ( $\leq 8$ nights).

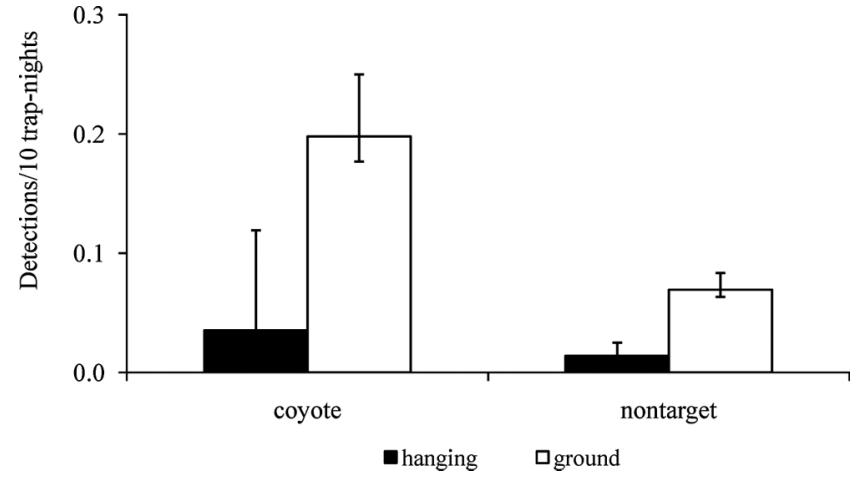

Figure 2. Number of detections/10 trap-nights for coyotes and nontarget species, obtained by using hanging and ground-based rub pads at Welder Wildlife Refuge, Sinton, Texas, USA, January 2003, 2004.

We obtained most samples from ground-based rather than hanging devices $(Z=4.20, P<0.001$; Fig. 2$)$. We did not observe a difference in efficacy between devices with carpet strips or screws at ground-based stations $(Z=-0.54$, $P=0.71)$. At WWR, sign at rub-station devices indicated feral pigs (Sus scrofa) visited, dug up, and destroyed hair snags, but did not leave hair behind. Some devices were also altered by cattle, mowing equipment, and unknown causes. The coyote was the only species identified to leave hair or scat at rub-station devices, but some hair samples lacked DNA or did not contain sufficient DNA for analyses, suggesting other species may have visited devices occasionally (Table 1 ).

\section{Montana: Wolves and Coyotes}

We could determine species origin for $58 \%$ of 99 samples representing $38 \mathrm{rub}$ events in Montana. Of these, 6 (16\%) were confirmed wolf, 1 (3\%) was deemed "likely wolf" based on 6 loci and sign at the device, $2(5 \%)$ mixed wolf and coyote, $10(26 \%)$ were coyote, $7(18 \%)$ were nontarget species, 9 (24\%) yielded insufficient DNA for full analysis, and 3 rubs (8\%) had too few hairs for DNA extraction (Table 2). We detected 8 individual wolves with $\geq 1$ individual from each of the 3 wolf packs.

Table 1. Summary of detections for rub-station devices used to elicit rub responses from coyotes at Welder Wildlife Refuge, Sinton, Texas, USA, in January 2003 and 2004.

\begin{tabular}{|c|c|c|c|c|c|c|c|}
\hline Placement & $\mathbf{Y r}$ & Device type & $N$ (stations) & Trap-nights & $\begin{array}{c}\text { Coyote } \\
\text { detections }\end{array}$ & $\begin{array}{l}\text { Nontarget or } \\
\text { unknown }\end{array}$ & $\begin{array}{l}\text { Insufficient DNA } \\
\text { or did not amplify }\end{array}$ \\
\hline \multirow[t]{5}{*}{ Ground } & 2003 & Carpet strip & 40 & 960 & 17 & 6 & $2^{\mathrm{a}}$ \\
\hline & & Screws & 15 & 360 & $7^{\mathrm{b}}$ & 3 & 0 \\
\hline & 2004 & Carpet strip & 50 & 1,200 & 24 & 8 & $6^{\mathrm{a}}$ \\
\hline & & Screws & $15^{\mathrm{c}}$ & 360 & 9 & 3 & 1 \\
\hline & Total & & 120 & 2,880 & 57 & 20 & 9 \\
\hline \multirow[t]{5}{*}{ Hanging } & 2003 & Carpet strip & 24 & 576 & 1 & 1 & 0 \\
\hline & & Screws & 11 & 264 & 0 & 0 & 0 \\
\hline & 2004 & Carpet strip & 17 & 408 & 2 & 1 & 2 \\
\hline & & Screws & 7 & 168 & 2 & 0 & 0 \\
\hline & Total & & 59 & 1,416 & 5 & 2 & 2 \\
\hline
\end{tabular}

\footnotetext{
${ }^{\text {a }}$ Extracted DNA desiccated in storage.

${ }^{\mathrm{b}}$ One of the 7 was a coyote visit but animal left no hair on device.

${ }^{\mathrm{c}}$ Destroyed by pig on 19 Jan, replaced with carpet strip.
} 
Table 2. Summary of detections for rub stations used to elicit rub responses from coyotes and wolves in Montana, USA, autumn 2008.

\begin{tabular}{lcccccc}
\hline Type & Trap-nights & $\begin{array}{c}\text { Wolf or } \\
\text { likely wolf }\end{array}$ & Coyote & $\begin{array}{c}\text { Mixed wolf } \\
\text { or coyote }\end{array}$ & $\begin{array}{c}\text { Nontarget or } \\
\text { unknown }\end{array}$ & $\begin{array}{c}\text { Insufficient DNA } \\
\text { or did not amplify }\end{array}$ \\
\hline Rub-station device & 303 & 4 & 8 & 0 & 6 & 9 \\
Sticks, debris & 85 & 3 & 2 & 2 & 1 & 3 \\
Total & 388 & 7 & 10 & 2 & 7 & 12 \\
\hline
\end{tabular}

We have limited evidence for relative efficacy of our lures given our samples sizes, but Mega Musk and Montana Special produced rubs by wolves in almost equal proportion, while OLLCC and fish derivative baits produced none. Median time to initial detection was 4 trap-nights $($ range $=2-10)$ for wolves, 5 trap-nights $($ range $=2-7)$ for coyotes, and 2 trap-nights (range $=2-10$ ) for nontarget species, with wolves having the highest detection rates (Fig. 3). We collected most hairs from the ground upon and around the rub-station devices instead of from barbs or bristles. Wolves rubbed more often on natural-material rub stations ( 0.6 detections/10 trap-nights) than at rub stations with a man-made collection device ( 0.1 detections/10 trapnights; $Z=2.47, P=0.007$ ).

\section{DISCUSSION}

We exploited the propensity of canids to rub on strong scents and noninvasively collected hairs from both coyotes and wolves in 2 different regions of the United States. The hairs we collected from rub-station devices provided high-quality DNA samples that were useful for identifying species (coyote vs. wolf) and individuals (wolf) and potentially would be useful for estimating other genetic metrics of interest for management and research.

Coyotes at WWR did not visit rub stations during summer and we hypothesize this is because coyotes may respond to scents differently during different seasons (Martin and Fagre 1988). July temperatures and humidity were much higher than in January at WWR. Because temperature and humidity affect efficacy of lures, some lures may elicit rub and rub

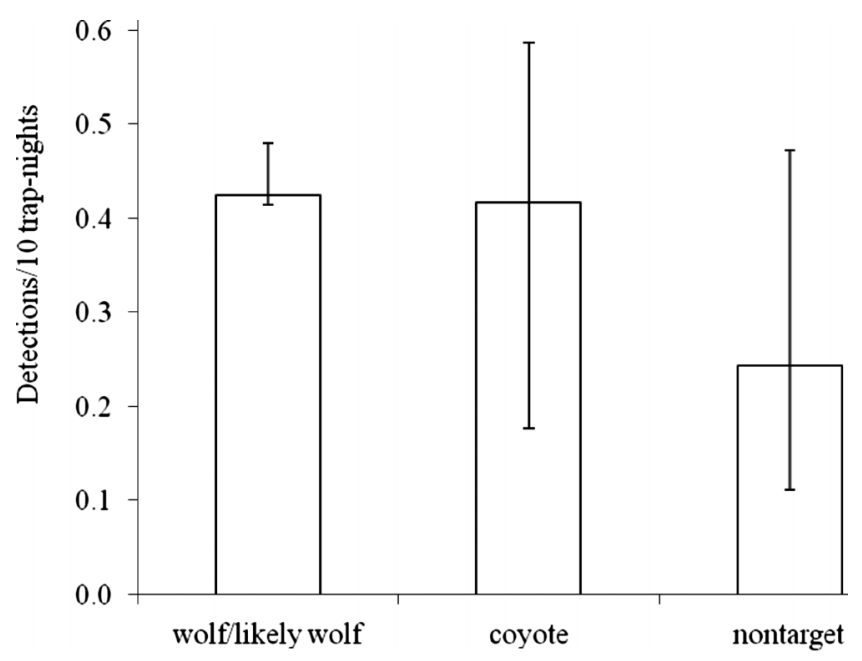

Figure 3. Minimum number of detections/10 trap-nights for wolves, coyotes, and nontarget species using lures and rub stations in western Montana, USA, autumn 2008. behavior from coyotes in summer months even though ours did not. We detected coyotes more frequently with groundbased devices than hanging devices. We hypothesize 2 possible explanations. First, hanging devices may have been less secure than ground-based devices; thus, the device moved with the coyote while it rubbed and, therefore, no hair was captured. Second, strong scents incite rub and rub behavior, which is a behavior more naturally performed on the ground by lowering a shoulder and rubbing the neck or shoulders (Ryon et al. 1986). Ground devices were more productive for collecting samples, although differences in behavior by individual coyotes (Gese and Ruff 1997, Darrow and Shivik 2009) may result in some coyotes only being detected by hanging devices.

We detected both wolves and coyotes at stations in northwestern Montana using both man-made and natural collection devices where lure was simply placed under debris. Approximately $60 \%$ of hair samples collected in Montana contained extractable DNA, whereas nearly $90 \%$ of samples from Texas had extractable DNA. The lower DNA-extraction success rates in Montana may be due to wet conditions encountered during sampling compared to the relatively drier conditions found in Texas (Waits and Paetkau 2005). If this is true, then more frequent device checks and rapid drying of hair samples may be beneficial. Alternatively, lower DNAextraction success rates in Montana could reflect a potential difference in extraction-success rates between hairs that were more likely shed (natural collection device) versus plucked hairs (man-made rub-station device; Goossens et al. 1998), although no study has empirically tested this hypothesis. Lastly, samples from Montana and Texas were stored differently and perhaps the storage method affected results.

In Montana, stations with natural collection devices were more effective for eliciting rubbing behavior and facilitating hair collection; we, therefore, hypothesize that canids may have an aversion to the presence of the man-made devices, but not lure. Contrary to results from Harrington and Asa (2003), neither wolves nor coyotes rubbed in fish-derivative baits. Most (70\%) coyote detections in Montana were obtained using OLLCC, whereas wolves were never detected using OLLCC, suggesting there may be differences in lure preferences between these 2 species. Perhaps equally as important as lure type is the amount of lure used at a rub station. Wolf biologists in the northern Rocky Mountains indicated they observed rubbing behavior when they inadvertently used excessive lure while trapping (L. Bradley, personal communication; M. Jimenez, personal communication) and, as a result, our sampling in Montana used relatively large amounts $(5 \mathrm{~mL}$ total at each rub station) of lure. Our data regarding preference for lure type and 
amount are limited, however, and require further exploration. Median time to detection in Montana was relatively short for wolves (4 nights), although we did sample in areas of known wolf use. Coyotes were detected within 5 nights and, in addition to the added value of providing a genetic sample, this rate compares favorably to rates for coyotes in the Adirondack Mountains, New York, USA, using noninvasive tools such as cameras (40 nights) and track-plates (0 detections in 4,068 nights; Gompper et al. 2006).

Our number of detections for wolves and coyotes in Montana is conservative because early laboratory extractions using 10-hair samples were less successful (46\%) than subsequent extractions using 20-hair samples (78\%); therefore, it is likely that some of the Big Hole and Ninemile pack samples would not have been classified as "insufficient DNA" had we used 20-hair samples at the beginning of our laboratory analyses. Using more hairs increases the likelihood of analyzing hairs that have viable DNA in attached roots, which are critical for DNA extraction (Waits and Paetkau 2005).

Our study demonstrated, in 2 different regions, that strongly scented lure and rub stations can be used to noninvasively collect hairs from coyotes and wolves. Exploiting behavior that encourages the deposition of a sample at a fixed location could improve the efficiency of hair collection over opportunistic sampling for these canids. Additionally, rub stations do not have to be visited daily (e.g., traps). Where rub-scented stations are deployed according to an appropriate sampling design, they could be used to provide estimates of abundance, measures of genetic diversity and health, and detection-nondetection data useful for cost-effective population monitoring (Joseph et al. 2006, Long and Zielinski 2008).

\section{MANAGEMENT IMPLICATIONS}

Rub stations may be particularly useful for surveying areas where distribution is unknown and detection-nondetection data are desired, in areas of presumed low density where traditional sign surveys may be ineffective, or where traditional capture methods are ineffective or infeasible. In addition to detection-nondetection data, rub stations provide genetic samples that can be used in areas where managers want to assess genetic diversity, relatedness, or ancestry of a sampled population. To use this method, we recommend:

1. Using ground-based devices to detect coyotes.

2. Using rub stations with natural collection devices to detect wolves.

3. If hairs have obvious roots, 10 hairs collected from a single device should constitute one sample for DNA analysis. When roots are not evident, 20 hairs should constitute one sample.

4. Checking stations at least every 4 nights. Longer times between rub-station checks can lead to multiple and mixed samples.

5. Using large amounts $(\geq 5 \mathrm{~mL})$ of lures that are sulfuric or smell of rotting meat.

\section{ACKNOWLEDGMENTS}

Funding was provided by the Wolf Recovery Foundation, Wilburforce Foundation, Idaho Department of Fish and Game, Nez Perce Tribe, Regina Bauer Frankenberg Foundation for Animal Welfare, National Wildlife Research Center, Sigma Xi, Rob and Bessie Welder Wildlife Foundation, and Leonard X. Bosack and Bette M. Kruger Foundation. Specifically, we thank L. Bradley, S. Brummer, J. Cox, J. Derbridge, R. Flatz, K. Holt, C. Mack, B. Martinez, R. Maughan, M. Panasci, C. Sime, C. Stansbury, J. Winans, and P. Zager for assistance and advice. We also thank D. Spicer and J. Husseman for early manuscript reviews. Anonymous reviewers greatly contributed to the strength of this manuscript and we appreciate their thorough reviews. This is Welder Wildlife Foundation Contribution 697.

\section{LITERATURE CITED}

Andelt, W. F., and S. H. Andelt. 1984. Diet bias in scat deposition-rate surveys of coyote density. Wildlife Society Bulletin 12:74-77.

Asa, C. S., and L. D. Mech. 1995. A review of the sensory organs in wolves and their importance to life history. Pages 287-291 in L. N. Carbyn, S. H. Fritts, and D. R. Seip, editors. Ecology and conservation of wolves in a changing world. Proceedings of the Second North American Symposium on Wolves. Canadian Circumpolar Institute, Occasional Publication no. 35, Edmonton, Alberta, Canada.

Ausband, D. E., M. S. Mitchell, K. Doherty, P. Zager, C. M. Mack, and J. Holyan. 2010. Surveying predicted rendezvous sites to monitor gray wolf populations. Journal of Wildlife Management 74:1043-1049.

Balme, G. A., L. T. B. Hunter, and R. Slotow. 2009. Evaluating methods for counting cryptic carnivores. Journal of Wildlife Management 73:433-441.

Barja, I., F. J. de Miguel, and F. Barcena. 2004. The importance of crossroads in faecal marking behaviour in wolves (Canis lupus). Naturwissenchaften 91(10):489-492.

Darrow, P. A., and J. A. Shivik. 2009. Bold, shy, and persistent: variable coyote response to light and sound stimuli. Applied Animal Behaviour Science 116:82-87.

De Veaux, R. D., P. F. Velleman, and D. E. Bock. 2004. Stats: data and models. Pearson Education, Upper Saddle River, New Jersey, USA.

Foran, D. R., S. C. Minta, and K. S. Heinemeyer. 1997. DNA-based analysis of hair to identify species and individuals for population research and monitoring. Wildlife Society Bulletin 25:840-847.

Gese, E. M., and R. L. Ruff. 1997. Scent-marking by coyotes, Canis latrans: the influence of social and ecological factors. Animal Behavior 54:11551166.

Gompper, M. E., R. W. Kays, J. C. Ray, S. D. Lapoint, D. A. Bogan, and J. R. Cryan. 2006. A comparison of noninvasive techniques to survey carnivore communities in northeastern North America. Wildlife Society Bulletin 34:1142-1151.

Goossens, B., L. P. Waits, and P. Taberlet. 1998. Plucked hair samples as a source of DNA: reliability of dinucleotide microsatellite genotyping. Molecular Ecology 7:1237-1241.

Gould, F. W. 1975. Texas plants-a checklist and ecological summary. Texas A\&M University Agricultural Experimental Station, College Station, USA.

Harrington, F. H., and C. S. Asa. 2003. Wolf communication. Pages 66103 in L. D. Mech, and L. Boitani, editors. Wolves: Behavior, ecology, and conservation. University of Chicago Press, Chicago, IL, USA.

Joseph, L. N., S. A. Field, C. Wilcox, and H. P. Possingham. 2006. Presence-absence versus abundance data for monitoring threatened species. Conservation Biology 20:1679-1687.

Kelly, M. J., and E. L. Holub. 2008. Camera trapping of carnivores: trap success among camera types and across species, and habitat selection by species, on Salt Pond Mountain, Giles County, Virginia. Northeastern Naturalist 15:249-262.

Kendall, K. C., and K. S. McKelvey. 2008. Hair collection. Pages 135-176 in R. A. Long, P. MacKay, W. J. Zielinski, and J. C. Ray, editors. 
Noninvasive survey methods for carnivores. Island Press, Washington, D.C., USA.

Kendall, K. C., J. B. Stetz, J. Boulanger, A. C. Macleod, D. Paetkau, and G. C. White. 2009. Demography and genetic structure of a recovering grizzly bear population. Journal of Wildlife Management 73:3-17.

Kimball, B. A., J. J. Johnston, J. R. Mason, D. E. Zemlicka, and F. S. Blom. 2000. Development of chemical coyote attractants for wildlife management applications. Proceedings of the Vertebrate Pest Conference 19:304309.

Kohn, M. H., E. C. York, D. A. Kamradt, G. Haught, R. M. Sauvajot, and R. K. Wayne. 1999. Estimating population size by genotyping faeces. Proceedings of the Royal Society of London, Biological Sciences 266:657663.

Long, R. A., and W. J. Zielinski. 2008. Designing effective noninvasive carnivore surveys. Pages 8-44 in R. A. Long, P. MacKay, W. J. Zielinski, and J. C. Ray, editors. Noninvasive survey methods for carnivores. Island Press, Washington, D.C., USA.

MacKay, P., W. J. Zielinski, R. A. Long, and J. C. Ray. 2008. Noninvasive research and carnivore conservation. Pages 1-7 in R. A. Long, P. MacKay, W. J. Zielinski, and J. C. Ray, editors. Noninvasive survey methods for carnivores. Island Press, Washington, D.C., USA.

Martin, D. J., and D. B. Fagre. 1988. Field evaluation of a synthetic coyote attractant. Wildlife Society Bulletin 16:390-396.

Marucco, F., D. H. Pletscher, L. Boitani, M. K. Schwartz, K. L. Pilgrim, and J. D. Lebreton. 2009. Wolf survival and population trend using noninvasive capture-recapture techniques in the western Alps. Journal of Applied Ecology 46:1003-1010.

McCall, B. 2009. Noninvasive genetic sampling reveals black bear population dynamics driven by changes in food productivity. Thesis, University of Montana, Missoula, USA.

Mowat, G., and C. Strobeck. 2000. Estimating population size of grizzly bears using hair capture, DNA profiling, and mark-recapture analysis. Journal of Wildlife Management 64:183-193.

Onorato, D., C. White, P. Zager, and L. P. Waits. 2006. Detection of predator presence at elk mortality sites using mtDNA analysis of hair and scat samples. Wildlife Society Bulletin 34:815-820.

Prugh, L. R., C. E. Ritland, S. M. Arthur, and C. J. Krebs. 2005. Monitoring coyote population dynamics by genotyping faeces. Molecular Ecology 14:1585-1596.

Ramsey, F. L., and D. W. Schafer. 2002. The statistical sleuth: a course in methods of data analysis. Duxbury, Pacific Grove, California, USA.
Ruell, E. W., and K. R. Crooks. 2007. Evaluation of non-invasive genetic sampling methods for felid and canid populations. Journal of Wildlife Management 71:1690-1694.

Ryon, J., J. C. Fentress, F. H. Harrington, and S. Bragdon. 1986. Scent rubbing in wolves (Canis lupus): the effect of novelty. Canadian Journal of Zoology 64:573-577.

Sargeant, G. A., D. H. Johnson, and W. E. Berg. 2003. Sampling designs for carnivore scent-station surveys. Journal of Wildlife Management 67:289298.

Schauster, E. R., E. M. Gese, and A. M. Kitchen. 2002. An evaluation of survey methods for monitoring swift fox abundance. Wildlife Society Bulletin 30:464-477.

Schwartz, M. K., and S. L. Monfort. 2008. Genetic and endocrine tools for carnivore surveys. Pages 238-262 in R. A. Long, P. MacKay, W. J. Zielinski, and J. C. Ray, editors. Noninvasive survey methods for carnivores. Island Press, Washington, D.C., USA.

Smith, J. B., J. A. Jenks, and R. W. Klaver. 2007. Evaluating detection probabilities for American marten in the Black Hills, South Dakota. Journal of Wildlife Management 71:2412-2416.

Stenglein, J. L., L. P. Waits, D. E. Ausband, P. Zager, and C. M. Mack. 2010. Efficient, noninvasive genetic sampling monitoring reintroduced wolves. Journal of Wildlife Management 74:1050-1058.

U.S. Fish and Wildlife Service, Nez Perce Tribe, National Park Service, and U.S. Department of Agriculture Wildlife Services. 2000-2008. Rocky Mountain wolf recovery annual report. U.S. Fish and Wildlife Service, Ecological Services, Helena, Montana, USA. <http://www.fws.gov/ mountain-prairie/species/mammals/wolf/>. Accessed 5 Jan 2010.

Vila, C., V. Urios, and J. Castroviejo. 1994. Use of faeces for scent marking in Iberian wolves (Canis lupus). Canadian Journal of Zoology 72:374-377.

Waits, L. P., and D. Paetkau. 2005. Noninvasive genetic sampling tools for wildlife biologists: a review of applications and recommendations for accurate data collection. Journal of Wildlife Management 69:1419-1433.

Western Regional Climate Center. 2009. <http://www.wrcc.dri.edu>. Accessed 11 Sep 2009.

Woods, J. G., D. Paetkau, D. Lewis, B. N. McLellan, M. Proctor, and C. Strobeck. 1999. Genetic tagging of free-ranging black and brown bears. Wildlife Society Bulletin 27:616-627.

Young, J. K. 2006. Spatial and behavioral ecology of coyotes in relation to food resources. Dissertation, Utah State University, Logan, USA.

Associate Editor: Applegate. 